SUBJECT AREAS:

MARINE BIOLOGY

DIFFERENTIATION

Received

10 December 2013

Accepted

20 June 2014

Published

9 July 2014

Correspondence and requests for materials should be addressed to

C.A.C. (cac@gate. sinica.edu.tw)

* These authors contributed equally to this work.

\section{Doors are closing on early development in corals facing climate change}

\author{
Shashank Keshavmurthy ${ }^{1 *}$, Silvia Fontana ${ }^{1,2,3 *}$, Takuma Mezaki ${ }^{4}$, Laura del Caño González ${ }^{1,5}$ \\ \& Chaolun Allen Chen ${ }^{1,2,6}$
}

\begin{abstract}
'Biodiversity Research Center, Academia Sinica, Taipei, 1 1529, Taiwan, ${ }^{2}$ Taiwan International Graduate Program - Biodiversity, Academia Sinica, Taipei, 1 1529, Taiwan, ${ }^{3}$ National Taiwan Normal University, Taipei, 106, Taiwan, ${ }^{4}$ Biological Institute on Kuroshio, Kochi, Otsuki, Nishidomari, 788-0333, Japan, ${ }^{5}$ Pierre and Marie Curie University, 4 Palace Jussieu, 75005, Paris, France, 'Institute of Oceanography, National Taiwan University, Taipei, 106, Taiwan.
\end{abstract}

Marine invertebrates are particularly vulnerable to climatic anomalies in early life history stages because of the time spent in the water column. Studies have focused on the effect of seawater temperature on fertilization, development, and larval stages in corals; however, none of them show comparative results along an environmental gradient. In this study, we show that temperatures in the range of $15-33^{\circ} \mathrm{C}$ have strong effects on fertilization rates and embryonic stages of two coral species, Acropora muricata in the subtropical environment and Acropora hyacinthus in subtropical and temperate environments.

Deformations after the first cleavage stages were observed at low $\left(15^{\circ} \mathrm{C}\right)$ and high $\left(33^{\circ} \mathrm{C}\right)$ temperatures. Development was delayed by 6-7 h in the slightly non-optimal temperature of $20^{\circ} \mathrm{C}$. We found significant differences in fertilization rates and responses of embryos from different latitudes, with temperate corals being more sensitive to extremely hot temperatures and vice versa. We hypothesize that the coral development is restricted to a narrow temperature range and deviation outside this window could inhibit a species' continuance and ecological success. Thus, it would have significant negative effects on adult populations and communities, playing a role in future of coral reef survival.

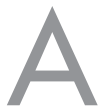

biotic factors such as seawater temperature fluctuations, acidification, salinity, typhoons, changing weather patterns, and habitat characteristics have been considered primary factors affecting the survival/physiological performance, fitness, and distribution of marine organisms ${ }^{1-6}$. Broadcast-spawning marine invertebrates fertilize their gametes externally and have motile larval stages that spend days to months in the water column, making them vulnerable to various environmental perturbation $s^{4,7}$. Thus, it is essential to consider multiple life stages when assessing a species' ability to tolerate stress. It is important for them to succeed at every stage of their early life cycle, including the fertilization of gametes, morula stage (also called the prawnchip stage due to its irregular concave shape), gastrulation (the so-called donut shape), motile larval stage, settlement, and growth ${ }^{4,5,8}$. These are critical life history phases for many organisms, especially when exposed to anthropogenic stressors. The importance of successful early stages is critical as it determines the long-term viability of local populations. In case of corals, this in turn can have community level consequences because they act as ecosystem engineers, providing habitat for myriad associated organisms while often excluding competitors for space?. Novel strategies or behaviors that increase overall reproductive success might be responsible for ensuring population survival ${ }^{4}$.

Studies conducted on scleractinian corals have shown conflicting results on fertilization rates when seawater temperature is a stress factor. While some studies observed no differences in fertilization rates with increasing temperatures ${ }^{10,11}$, an increase in cleavage rates were found in the corals Favites abdita, F. chinensis, and Mycedium elephantotus ${ }^{12}$, and A. millepora showed reduced fertilization ${ }^{12}$. Studies on other non- coral marine invertebrates have shown that when seawater temperature is used as a stress factor, fertilization is not affected but subsequent life stages are vulnerable ${ }^{8}$.

Like other marine invertebrates, corals are facing their threshold limits as they respond to seawater temperature fluctuations and other ocean changes ${ }^{13-16}$. Studies have shown the presence of interspecific differences in their response to seawater temperature stress during their early stages ${ }^{10,12,17}$. At higher temperatures there is increased mortality, low rates of early stage development, increased embryonic abnormalities, reduced survival of larvae, shorter pre-settlement times ${ }^{10,12,18-23}$, and the bleaching and death of adult corals ${ }^{24-36}$. The sensitivity of developmental stages (low fertilization and high juvenile mortality rates) in corals to increasing seawater temperatures might result in a bottleneck for species persistence and ecological success, thereby having a negative effect on adult 
populations and communities ${ }^{4}$. Therefore, documenting the effects of temperature on early life stages is fundamental for understanding the potential for long-term resistance in corals to changing environmental conditions. Numerous studies (laboratory-based aquarium tank experiments and field-based sampling and observations) have been conducted to observe the responses of corals to seawater temperature stress in adults ${ }^{24-36}$ as well as larvae and pre-motility (fertilization and embryonic stages) stages $^{11,37-41}$ (see Table 1 and references cited therein). However, there is a lack of information on how seawater temperatures that parent colonies are exposed to over the long term affect fertilization and development and whether the effects are the same at different latitudes. Furthermore, only a single study ${ }^{42}$ used gametes from known parent colonies and thus considered the genotypic effect on the response to temperature stress.

Studies have reported that the ideal temperature for fertilization and early development is $25-28^{\circ} \mathrm{C}^{23,43}$, whereas in cases of adult corals bleaching is observed at sea water temperatures around $31^{\circ} \mathrm{C}\left(1-2^{\circ} \mathrm{C}\right.$ higher than the average summer seawater temperature $)^{44-46}$ in tropical areas. However, the range of temperatures in which adult coral can thrive is between $\sim 15^{\circ} \mathrm{C}^{47}$ (temperate) to $\sim 35^{\circ} \mathrm{C}$ (in Persian Gulf) ${ }^{48}$. This suggests early developmental stages might be particularly sensitive to temperature stress. Hence, it is important to understand the effects of temperature on pre-settlement in order to understand how recruitment is influenced by external factors.

Here we report the effects of various seawater temperatures (at 15, $20,25,28$, and $33^{\circ} \mathrm{C}$ ) on the fertilization success, survival ratio, and development in two coral species: Acropora hyacinthus, at Penghu Marine Biology Research Center (PMBRC), Penghu, Taiwan (subtropical) and at the Biological Institute of Kuroshio (BIK), Kochi, Japan (temperate); and Acropora muricata at PMBRC (subtropical) (Fig. 1). We performed three different trials, one for A. muricata and two for A. hyacinthus. In each trial we exposed unfertilized gametes and subsequent embryo stages to five temperature treatments $(15,20$, 25,28 , and $33^{\circ} \mathrm{C}$ ). We crossed the gametes from three different colonies (for a total of six crosses, since we separated the maternal and paternal gametes from each hermaphrodite colony), with three replications for each cross, for a total of 18 repetitions per treatment (Fig. 2). Furthermore, we included three replicates for self-fertilization and controls (eggs cultivated in sperm-free sea water) (Fig. 2). We hypothesized that there are inter- and intraspecies differences in their responses to seawater temperature stress and that the variations between the two locations were due to local adaptations to latitudinal differences. In addition, we tested for variability between colony crosses due to the genotypic effect on survival rate.

\section{Results}

Seawater temperatures at two study locations. Data loggers deposited at Penghu Kochi recorded hourly seawater temperature for a period of 14 months (Fig. 3). The minimum, maximum, and mean winter (January) temperatures were $14.5^{\circ} \mathrm{C}, 28.0^{\circ} \mathrm{C}$, and $17.2 \pm$ $3.5^{\circ} \mathrm{C}$, respectively, in Penghu and $12.2^{\circ} \mathrm{C}, 18.7^{\circ} \mathrm{C}$, and $16.9 \pm$ $1.0^{\circ} \mathrm{C}$, respectively, in Kochi. Minimum, maximum, and mean summer (August) temperatures were $25.8^{\circ} \mathrm{C}, 29.1^{\circ} \mathrm{C}$, and $27.1 \pm$ $0.6^{\circ} \mathrm{C}$, respectively, in Penghu and $25.1^{\circ} \mathrm{C}, 29.6^{\circ} \mathrm{C}$, and $28.0 \pm$ $0.6^{\circ} \mathrm{C}$, respectively, in Kochi. The experiment in Kochi was conducted in August 2012. In Penghu, the experiment was conducted in May 2012 when minimum and maximum seawater temperatures were $23.8^{\circ} \mathrm{C}$ and $30.8^{\circ} \mathrm{C}$ and the mean temperature was $25.8 \pm 0.9^{\circ} \mathrm{C}$. The transition in seawater temperatures from winter to summer was sharper in Penghu than Kochi (Fig. 3).

Fertilization and development time. Development in both $A$. muricata and A. hyacinthus (Fig. 4) was consistent with previous observations for other congeneric species ${ }^{49-52}$ until $24 \mathrm{~h}$ when they reached the "donut stage." Although not completely overlapping, a similar pattern was observed in our study in the time required to achieve motility and develop into spindle planular larvae. $A$. muricata became motile after $41 \mathrm{~h}$ and A. hyacinthus after $38 \mathrm{~h}$ in both localities.

Effect of temperature on fertilization and development. There were differences in fertilization and development rates between temperature treatments in all three trials (Fig. 5). In all experiments, optimum fertilization and development were observed to occur at $25^{\circ} \mathrm{C}$ (Fig. 5), although the control temperature (ambient seawater temperature at the time of sampling and experimentation) was around $28^{\circ} \mathrm{C}$ at both locations. Each stage of the embryonic cycle (prawn chip, donut, and pear) took the same amount of time for completion under 25 and $28^{\circ} \mathrm{C}$ conditions (Fig. 6, 7, 8). At $20^{\circ} \mathrm{C}$ there was a delay in developmental time, and at $15^{\circ} \mathrm{C}$ fertilization was delayed by $6-7 \mathrm{~h}$ (Fig. 6, 7, 8). At the last observed stage (motile larvae), no survivors were observed at the more extreme temperatures $\left(15^{\circ} \mathrm{C}\right.$ and $\left.33^{\circ} \mathrm{C}\right)$, the exceptions being in both species at PMBRC at $33^{\circ} \mathrm{C}$ with few survivors. Healthy larvae were observed to have high survival percentages at optimal temperatures $\left(25^{\circ} \mathrm{C}\right.$ and $28^{\circ} \mathrm{C}$ ) (Figs. 5, 6, 7, 8). Treatments at 15,20 , and $33^{\circ} \mathrm{C}$ showed large variations (5-100\%) in the number of eggs fertilized and those that underwent development. Although high mortality was observed at $20^{\circ} \mathrm{C}$, a small percentage of the survivors reached the last stage (motile larvae) successfully (Figs. 5, 6, 7, 8). Responses to the $20^{\circ} \mathrm{C}$ treatment showed high variability (Fig. 5).

Inter- and intra-location variation in fertilization and development of A. hyacinthus at PMBRC and BIK. Fertilization success rates showed differences between the two localities at $33^{\circ} \mathrm{C}$ (Fig. 5, central and right columns). Although PMBRC (subtropical) fertilization success rates were highly variable at 15 and $20^{\circ} \mathrm{C}$, and $100 \%$ at $33^{\circ} \mathrm{C}$ (Fig. 5), at BIK (temperate) we observed the opposite, with almost $100 \%$ fertilization at 15 and $20^{\circ} \mathrm{C}$ and a sharp drop to $<30 \%$ at $33^{\circ} \mathrm{C}$ (Fig. 5). In the PMBRC trial, no survival was observed after fertilization at $15^{\circ} \mathrm{C}$, while at $33^{\circ} \mathrm{C}$ an average of 60 and $40 \%$ of individuals reached the prawn-chip and donut stages, respectively. Conversely, no survivorship was observed in post-fertilization stages at 15 and $33^{\circ} \mathrm{C}$ in the BIK trial (Figs. 5, 7, 8). Development only rarely reached the motile phase at lower and higher temperatures, with only a few individuals still alive and functional at $33^{\circ} \mathrm{C}$ at PMBRC (Fig 5). At the sub-optimal temperature of $20^{\circ} \mathrm{C}$, better performance was observed in BIK with respect to $\mathrm{PMBRC}$, with a higher average percentage of survival at every stage (Figs. 5, 7, 8). Multiple comparison results showed significant differences $(\mathrm{p}=0.0001)$ in fertilization between locations at $33^{\circ} \mathrm{C}$, with $A$. hyacinthus in BIK having lower rates compared to PMBRC (Fig. 5, Table 2). Similarly, there was a significant difference $(p=0.001)$ in prawn chip stage development at $33^{\circ} \mathrm{C}$, with A. hyacinthus at BIK being more sensitive compared to PMBRC. There were no significant differences between the species in all other stages and temperature treatments (Fig. 5, Table 2).

Inter- and Intraspecies variation in fertilization and development of gametes at PMBRC. The general trends were similar for A. muricata and A. hyacinthus at PMBRC (Fig 5, left and central columns). Difference was found between the two species only in fertilization at $15^{\circ} \mathrm{C}$, and the slight differences generally observed can be explained by inter-colony variation (see below). There were no differences in the effects of temperature stress on developmental stages between the two species. However, in the $33^{\circ} \mathrm{C}$ treatments, an average of $30 \%$ of $A$. muricata did reach the motile stage (Figs. 5,6) while a few individuals of $A$. hyacinthus survived later than the donut stage (Figs. 5, 7). Treatments at 15,20 , and $33^{\circ} \mathrm{C}$ showed a large variation (5-100\%) in the number of eggs fertilized and those that underwent development. There was more variation within A. muricata, which showed significant differences between temperature treatments $(\mathrm{p} \leq$ 
Table 1 | Summary of available information on experiments conducted to observe the effects of different stresses on early development stages in corals. **Fertilization *Pre larval stages

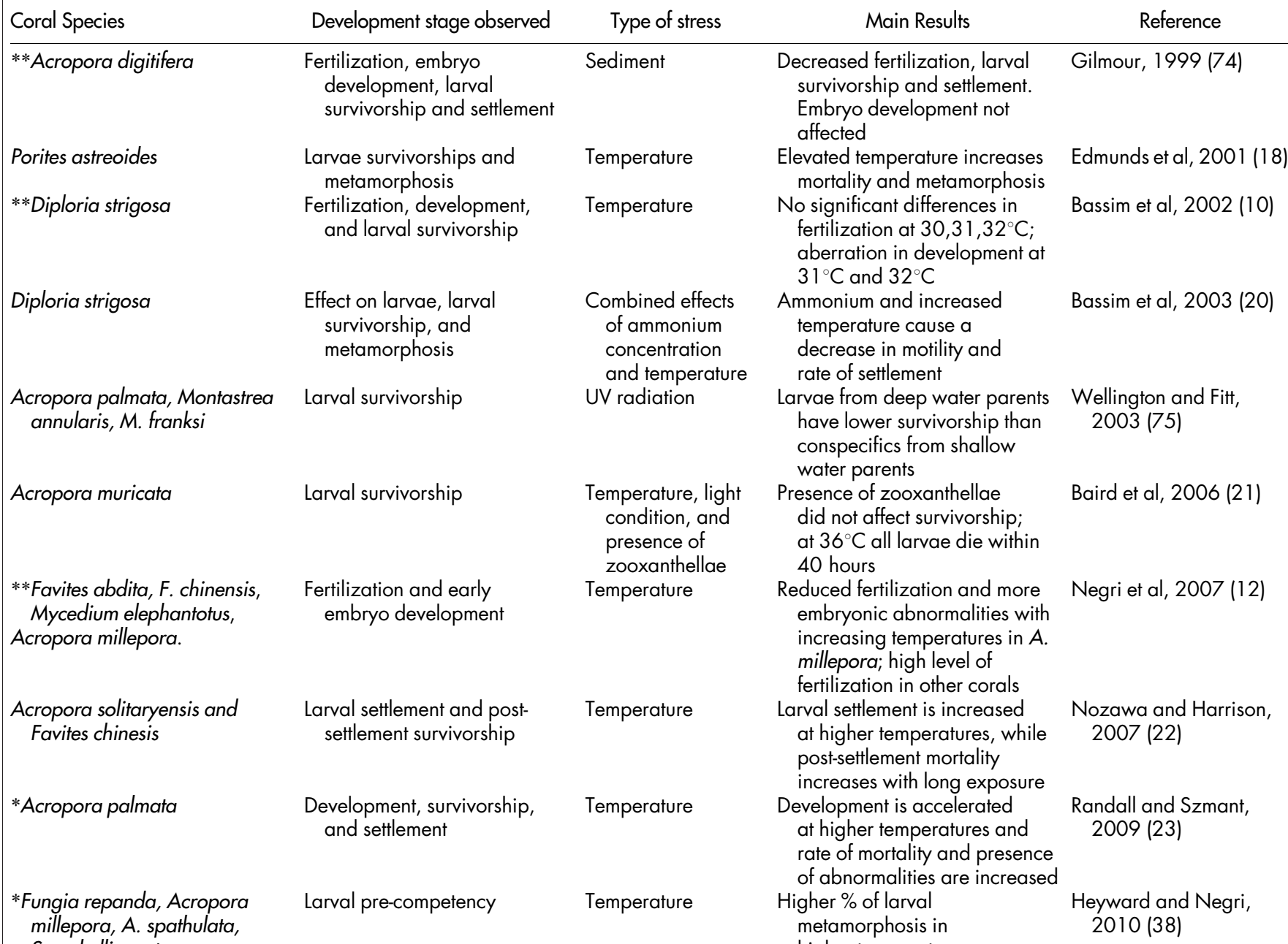

Larval survivorship and settlement, and growth into primary polyps

\section{*Montastraea faveolata \\ Pocillopora damicornis, Seriatopora hystrix, and Stylophora pistillata} Acropora millepora, A. tenuis

Goniastrea retiformis and Leptastrea cf transversa **Acropora palmata

**Acropora tenuis, Acropora millepora

* Goniastrea favulus, Acropora spathulata

\section{Early embryo stages sensitivity}

Larval respiration

Larval metamorphosis

Larval metamorphosis and settlement

Fertilization and development

Fertilization, development, survivorship, and settlement

Embryo and larval survivorship

\section{Combined effect of temperature and $\mathrm{CO}_{2}$}

UV radiation

higher temperatures

Survival and settlement unaffected by increasing $\mathrm{CO}_{2}$ and $1{ }^{\circ} \mathrm{C}$, polyp growth reduced by the combined effect

Low sensitivity during early development; susceptibility in the motile planula stage

Temperature

Combined effects of copper contamination and temperature $\mathrm{CO}_{2}$

Respiration rate was parabolic in relation to temperature, peaking at $28^{\circ} \mathrm{C}$

Synergic interactions: reducing Cu concentration prevents negative effect of $2-3^{\circ} \mathrm{C}$ increase

No direct effects of acidification

Genotypic diversity affects the response of fertilization and developmental success effect of differen genotypes

Combined effects of $\mathrm{CO}_{2}$ and temperature

No effect of $\mathrm{CO}_{2}$; no effect of $2{ }^{\circ} \mathrm{C}$ difference on fertilization, survivorship, and metamorphosis, increases rate of development

Temperature

Slower development at $20^{\circ} \mathrm{C}$
Anlauf et al, 2011 (39)

Aranda et al, 2011 (76)

Edmunds et al, 2011 (37)

Negri and

Hoogeneboom,

2011 (40)

Chua et al, 2012 (77)

Baums et al, 2013 (42)

Chua, 2013 (11) Temperature above ambient lower survival. A. spathualata is more affected that $G$. favulus 


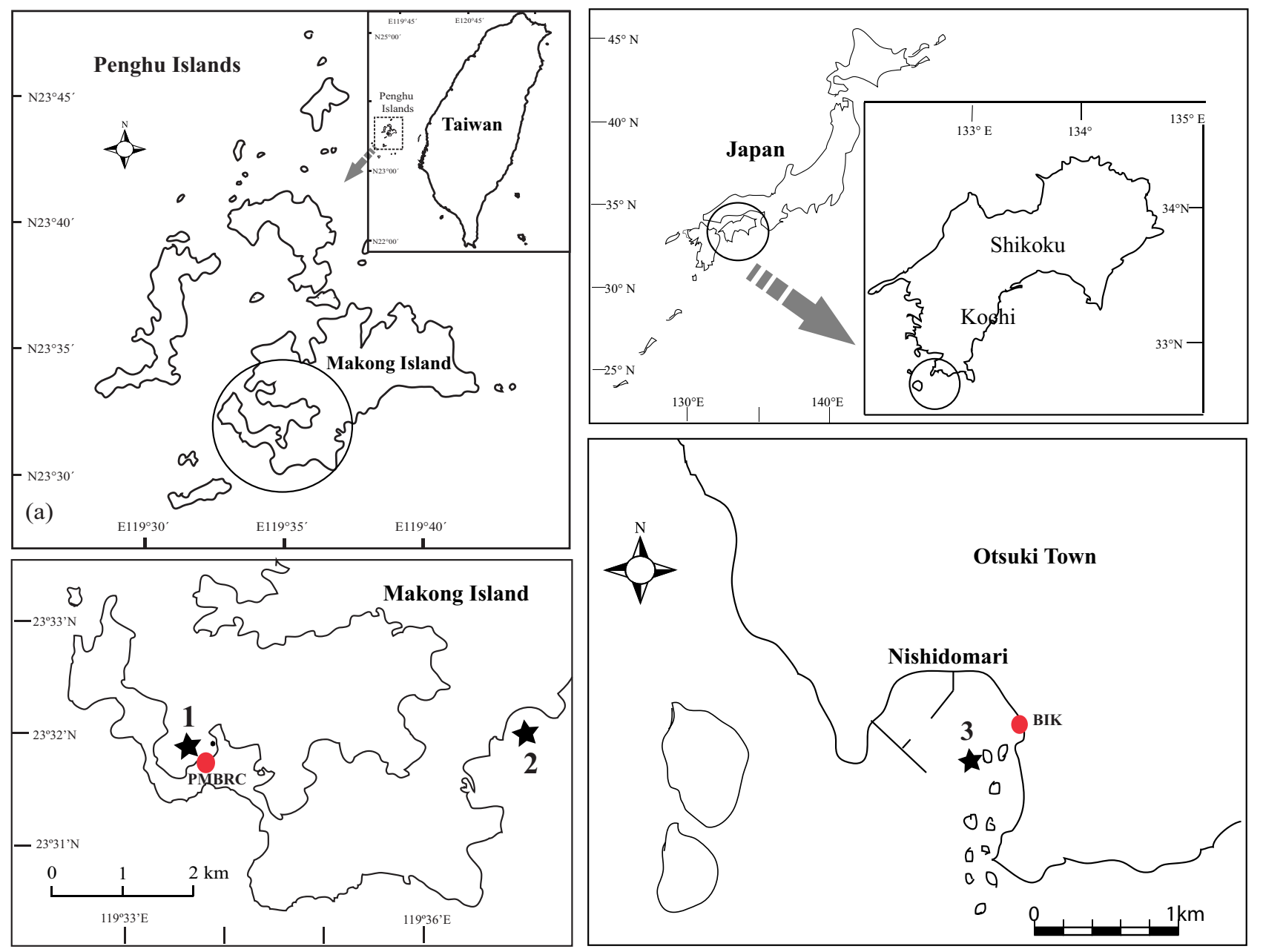

Figure $1 \mid$ Map of sampling locations and crossing experiments in subtropical Penghu, Taiwan (PMBRC) and temperate Kochi, Japan (BIK). Location of PMBRC and BIK are shown as red filled circles and sampling locations are shown as black stars. The maps were drawn using the software Magic Maps ver. 1.4.3 and Adobe Illustrator CS5 (Macintosh version).

0.001 for the fertilization, donut, and pear stages, and $\mathrm{p} \geq 0.01$ for the prawn chip stage) (Fig. 5). However, A. hyacinthus had lower and very few significant differences to temperature stress ( $\mathrm{p} \leq 0.01$ in the pear stage and $\mathrm{p} \leq 0.05$ in the donut stage). Multiple interspecific comparisons between A. muricata and A. hyacinthus from PMBRC showed that the fertilization rate was significantly different between the two species only at $15^{\circ} \mathrm{C}(\mathrm{p}=0.01)$ (Table 3$)$.

Inter- and intra-cross (between repetitions) variation. High variability was observed in many cases within each treatment, especially at non-optimal temperatures such as 15,20 , and $33^{\circ} \mathrm{C}$ (Fig. 5, high standard deviations are shown in the bar, especially at 15 and $20^{\circ} \mathrm{C}$ ). For example, in the $15^{\circ} \mathrm{C}$ treatment with $A$. hyacinthus at PMBRC, a 50\% fertilization average was observed, while the range of fertilization among repetitions was $0-100 \%$. We observed the maximum variability in the $20^{\circ} \mathrm{C}$ treatment. We therefore performed a statistical analysis on the response of each cross to verify whether the variability was due to genotypic differences among the colonies used in the experiment (Figs. 9 A, B, C). We found inter-cross differences in fertilization at 15 and $20^{\circ} \mathrm{C}$ treatments for both species at PMBRC and subsequently at $20^{\circ} \mathrm{C}$ for prawn chip, donut, and pear stages (Fig. 9 A, B, Table 4). A multiple comparison analysis showed that $A$. muricata crosses at PMBRC (Fig. 9 A) exhibited significant differences in fertilization among some crosses at 15 and $20^{\circ} \mathrm{C}(\mathrm{p}=0.001$ and $\mathrm{p}=0.002$; Table 4$)$ and less significant differences in other stages $(p=0.02$;
Table 4). However, there were no significant differences among crosses at higher temperatures $\left(25,28\right.$, and $\left.33^{\circ} \mathrm{C}\right)$. In the case of $A$. hyacinthus from PMBRC (Fig. $9 \mathrm{~B}$ ), the difference was less significant $(\mathrm{p}=0.02)$ between the cross at 15 and $20^{\circ} \mathrm{C}$ for fertilization but showed greater significance in other stages $(\mathrm{p}=0.001)$ (Table 4$)$. Unlike $A$. muricata, a significant difference $(\mathrm{p}=0.001)$ was seen between crosses at $33^{\circ} \mathrm{C}$ in the donut stage (Table 4). A. hyacinthus from BIK (Fig. 9 C) showed significant differences $(p=0.001)$ between crosses only for fertilization, prawn chip and donut stages at $20^{\circ} \mathrm{C}$ (Table 4$)$.

Aberrant development of the embryos. Aberrations in embryo development were detected at low $\left(15^{\circ} \mathrm{C}\right)$ and high $\left(33^{\circ} \mathrm{C}\right)$ temperatures. At $15^{\circ} \mathrm{C}$, developmental deformations were observed immediately after fertilization, which was delayed by $2-3 \mathrm{~h}$. Irregular and disproportional cell divisions were observed at $\sim 9 \mathrm{~h}$ after fusion of fertilized eggs. For this reason, embryos never reached the prawnchip stage, instead continuing to fuse and degrade until the end of the experiment. This pattern was consistent for all three trials (two at PMBRC and one at BIK).

At $33^{\circ} \mathrm{C}$, fertilization was faster than optimal conditions $\left(25^{\circ} \mathrm{C}\right.$ and $28^{\circ} \mathrm{C}$ treatment) by $\sim 1$ hour and was often followed by rapid and irregular cell division. At $\sim 9 \mathrm{~h}$, cell division had stopped and aberrant embryos started to degrade. Although all fertilized A. hyacinthus embryos at BIK underwent degradation, some fertilized embryos in both PMBRC trials were non-aberrant and survived till the end of the 

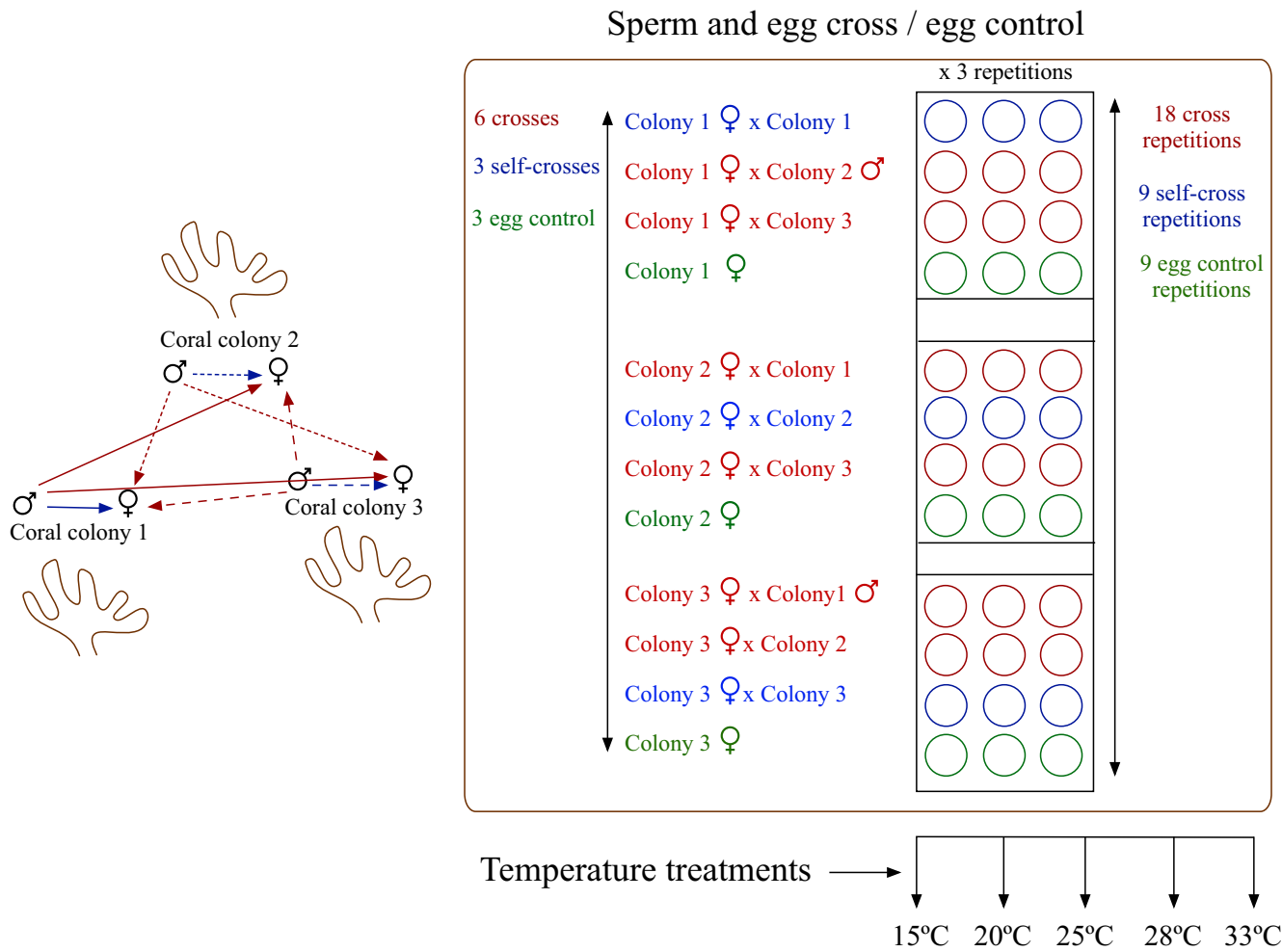

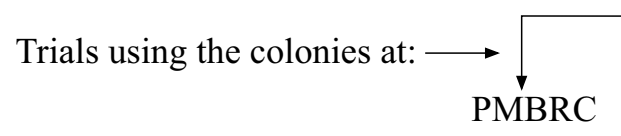

A. muricata

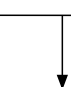

PMBRC

A. hyacinthus same spawning year (2012) by conducting separate parental trials. The optimal temperature for survival after fertilization and before motility was $25^{\circ} \mathrm{C}$ irrespective of latitudinal differences in the seawater temperatures that corals are exposed to during gametogenesis and spawning. Although survival was highly affected by temperature of 15 and $33^{\circ} \mathrm{C}$, this effect was different at the two latitudes. We posit that a narrow range of suitable seawater temperatures for early development in corals will create bottlenecks when seawater temperatures rise $2.0-3.0^{\circ} \mathrm{C}$ by $2050^{4,53}$. This study is first to show in detail the effects of temperature on different stages of coral development as a function of latitude and species.

This study is the first to address the effects of seawater temperat on the fertilization and early development in identical coral species living at two latitudes (subtropical and temperate) and during the

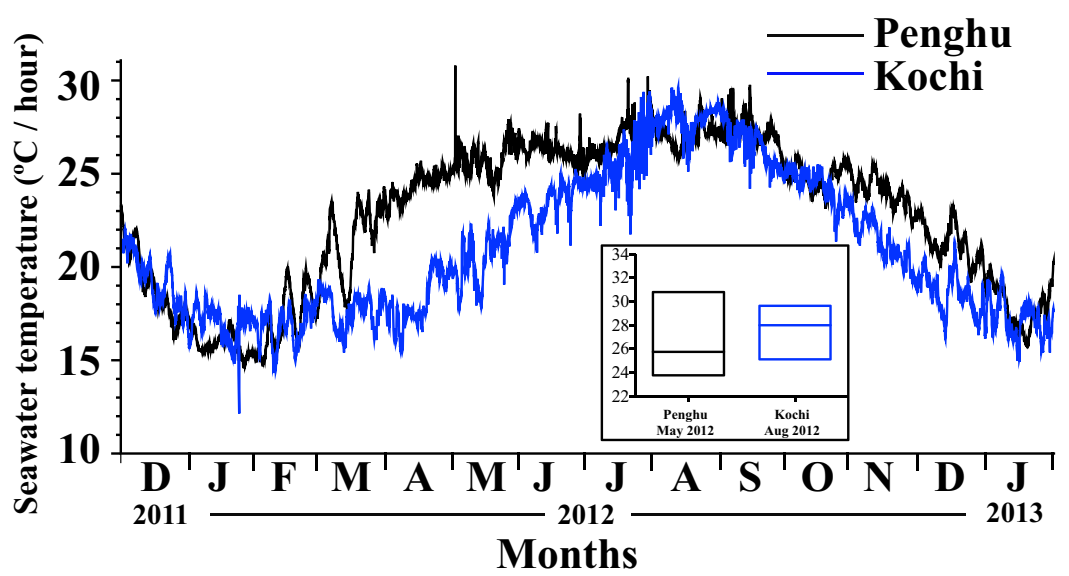

Figure 3 | Seawater temperature plot at Penghu (subtropical) and Kochi (temperate). Values represent hourly seawater temperatures plotted from December 2011-January 2013. The inset box plot represents seawater temperatures for those months in which the experiments were carried out at two locations. 


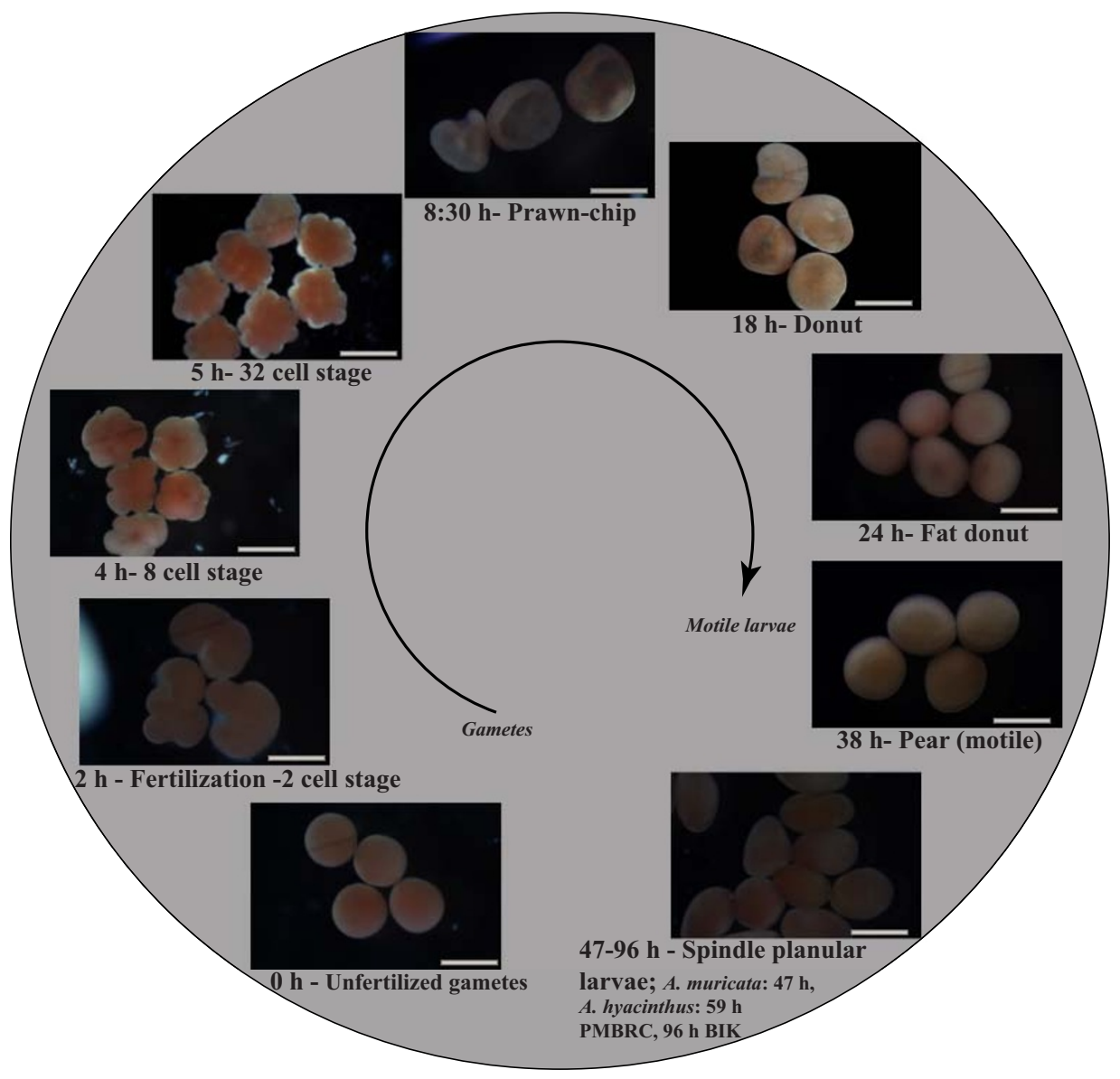

Figure $4 \mid$ Embryo stages at ambient temperature from unfertilized gametes $(0 \mathrm{~h})$ to planular larval stage $(46-96 \mathrm{~h})$. Scale bar $=500 \mu \mathrm{m}$.

The timing of developmental stages was similar for A. muricata and $A$. hyacinthus at both localities (Fig. 4) and congruent with the developmental cycles of other Acropora species ${ }^{49-52}$ for the first $24 \mathrm{~h}$. Although not completely overlapping with the previous study ${ }^{51}$ a similar pattern was observed in the time required to achieve motility and develop into spindle planular larvae. A. muricata became motile after $41 \mathrm{~h}$ in this study, whereas it was previously observed ${ }^{52}$ to attain motility after $47 \mathrm{~h}$ in the same location (PMBRC). Similarly, A. hyacinthus became motile after $38 \mathrm{~h}$ in both localities, whereas ${ }^{50}$ found that it gained motility after only $36 \mathrm{~h}$ in concomitance with three other Acropora species. These slight differences may be due to different observation times during the experiments. Major differences were observed in this study between species and localities and with respect to previous studies in the time it takes to develop into spindle planular larvae. This last stage can be influenced by external conditions ${ }^{51}$.

Our latitudinal comparison showed that gametes from temperate Japan were susceptible to the high temperature of $33^{\circ} \mathrm{C}$, but gametes of the same species from sub-tropical Taiwan were less sensitive (Fig. 5). In a similar study ${ }^{54}$, it was observed that the effect of temperature on the development of crown-of-thorns starfish depends on the geographic source of its larvae and the recent history of adult temperature exposures. Above or below the predicted temperature range $\left(25-28^{\circ} \mathrm{C}\right)$, development was either delayed with a high frequency of subsequent death $\left(20^{\circ} \mathrm{C}\right)$ or deformations in developmental stages occurred ( 15 and $33^{\circ} \mathrm{C}$ ) (Figs. 6-8). Aberrant development was observed at lower and higher temperatures after the first cell division (Figs. 6-8). Aberrant embryos showed irregular cell division and fusion, always followed by degradation. Similarly, A. millepora showed deformed development at $32^{\circ} \mathrm{C}$ after the first cleavage stage ${ }^{12}$, while abnormalities in Diploria strigosa were observed later in their development ${ }^{10}$. However, gametes were able to fertilize at all temperatures they were exposed to, but at a significantly lower rate in the $33^{\circ} \mathrm{C}$ treatment for A. hyacinthus at BIK (Fig. 5). This might be because all ontogenic stages of a life cycle are exposed to environmental conditions, so population persistence depends on the performance of adults and offspring. However, if seawater temperatures become non-conducive for coral developmental stages, corals would have to shift their spawning away from summer by either advancing or delaying gametogenesis to cooler months ${ }^{8}$. Less affected fertilization rates can be attributed to stress resistant traits passed on directly to gametes from parents and genes for stress resistance in fertilized gametes not being expressed until after fertilization ${ }^{4}$. However, during the late stages of embryonic development, the differential expression of genes affects their ability to respond to particular stresses.

Studies on the fertilization of other marine invertebrates such as echinoids, polychaetes, mollusks, and echinoderms also indicate that gametes have the ability to fertilize over a wide temperature range (4$15^{\circ} \mathrm{C}$ ) above local ambient fertilization temperatures ${ }^{4}$. Similarly, found ${ }^{10}$ no significant differences in fertilization success rates at 30 , 31 , and $32^{\circ} \mathrm{C}$ in Diploria strigosa, but developmental aberrations were observed at 31 and $32^{\circ} \mathrm{C}$. At elevated temperatures $\left(+5^{\circ} \mathrm{C}\right.$, $26-32^{\circ} \mathrm{C}$ ), high levels of abnormalities and reduced fertilization rates occur in Acropora millepora and increased cleavage rates occur in Favites chinensis, F. abdita, and Mycedium elephantotus ${ }^{12}$. The developmental sequence in Acropora palmata was faster at 30 and $31.5^{\circ} \mathrm{C}$ than $28^{\circ} \mathrm{C}$, but at higher temperatures greater rates of abnormal embryo development occur ${ }^{23}$. A similar response was observed in other marine invertebrates (e.g., oyster, sea urchin) tested for fertilization and development success at high temperatures ${ }^{4,55}$.

Our observations lead us to believe that the present increase in seawater temperatures will affect embryonic development and might 
Fertilized

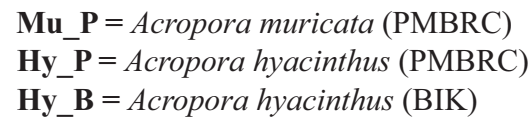

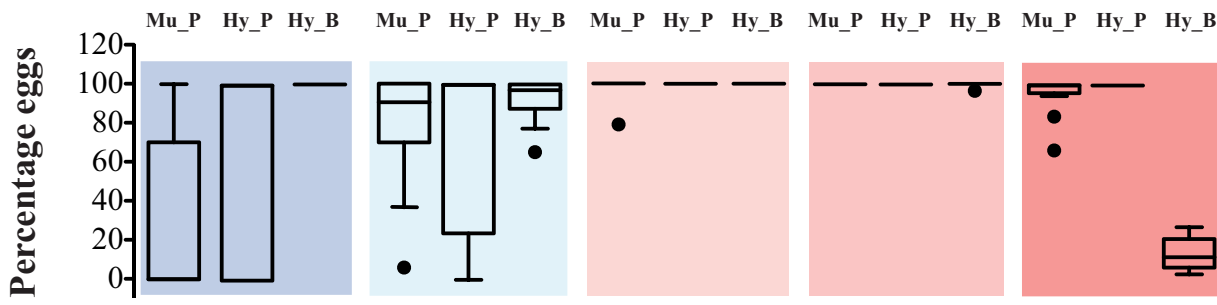

Prawn Chip stage
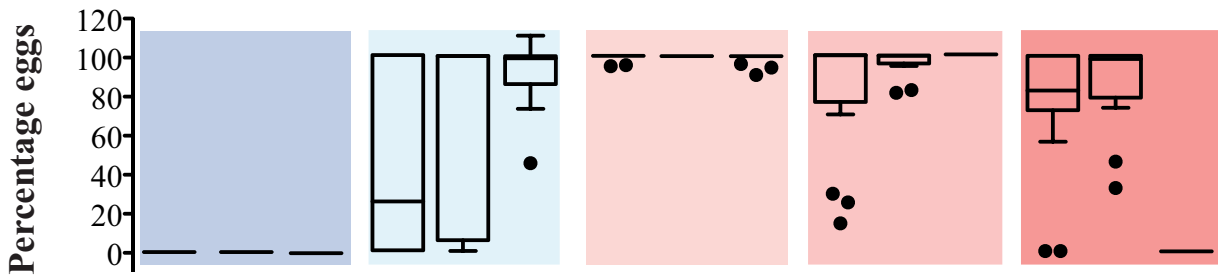

Donut stage
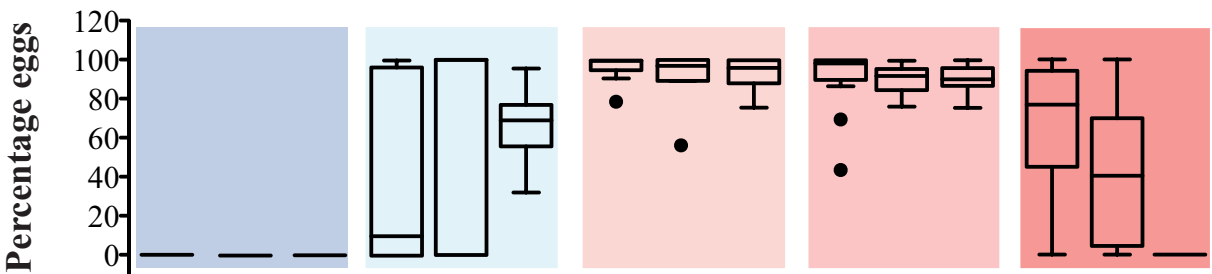

\section{Pear stage}

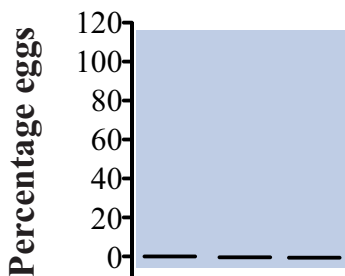

15

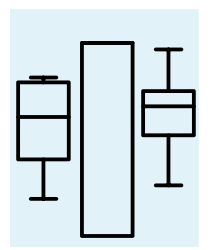

20

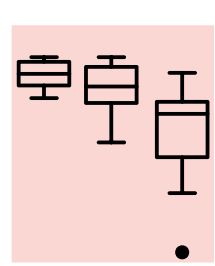

25

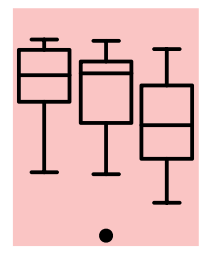

28

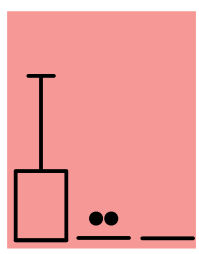

33

\section{Temperature $\left({ }^{\circ} \mathrm{C}\right)$}

Figure 5 Quantitative data for fertilization; prawn chip, donut, and pear stages at different temperature treatments $\left(15,20,25,28\right.$, and $33^{\circ} \mathrm{C}$ columns are in different colors). The percentages of individuals reaching each stage that appeared healthy and non-aberrant are plotted. Three bars are depicted for each trial, which correspond to treatments performed with A. muricata in PMBRC (left bar), A. hyacinthus in PMBRC (central bar), and A. hyacinthus in $\mathrm{BIK}$ (right bar). $\mathrm{Mu} \_\mathrm{P}=$ A. muricata in PMBRC, Penghu; Hy_P $=$ A. hyacinthus in PMBRC, Penghu, and Hy_B $=$ A. hyacinthus in BIK, Kochi. The box indicates the 25th and 75th percentiles, and the line within the box marks the median. Whiskers below and above the box indicate the 10th and 90th percentiles.

influence fertilization rates under more extreme conditions. This outcome might influence the timing of gametogenesis and spawning $^{56}$. In fact, water temperature affects the timing of reproduction for many invertebrates ${ }^{41,57,58}$, including corals ${ }^{56}$. It will also result in a decrease in the survival of corals at later life stages ${ }^{10,23}$, thus determining the long-term viability of local populations ${ }^{9}$. Our results show that temperatures deviating $\pm 5^{\circ} \mathrm{C}$ from the optimal development temperatures of $25-28^{\circ} \mathrm{C}$ affected gamete development. This implies that a temperature fluctuation of $\pm 5^{\circ} \mathrm{C}$ will severely affect coral developmental stages in spite of their gametes being fertile. Corals will face greater seawater temperature fluctuations in the ocean change scenario when tropical corals are hypothesized to migrate to higher latitudes ${ }^{59,60}$. In this event, it might result in the early life stages of corals being more impacted than adult corals since the latter are known to thrive in seawater temperatures above $35^{\circ} \mathrm{C}$ in places like the Persian Gulf ${ }^{48}$ or also tolerate daily fluctuations in seawater temperature (up to $10^{\circ} \mathrm{C}$ ) as a result of internal waves and upwelling ${ }^{61}$.

Our study also showed how parental lineage genotypes had a certain degree of influence on organism survival, especially genotype under high selective pressure at sub-optimal conditions (such as $20^{\circ} \mathrm{C}$, see figs. $5,9 \mathrm{~A}, \mathrm{~B}, \mathrm{C}$, Table 4 ). We performed separate trials in this study for each parent cross (which was previously done only by ${ }^{41}$ ), applying a series of different seawater temperatures to coral embryo stages to determine the role of genotype in reproductive success. We observed differences between crosses at different stages 


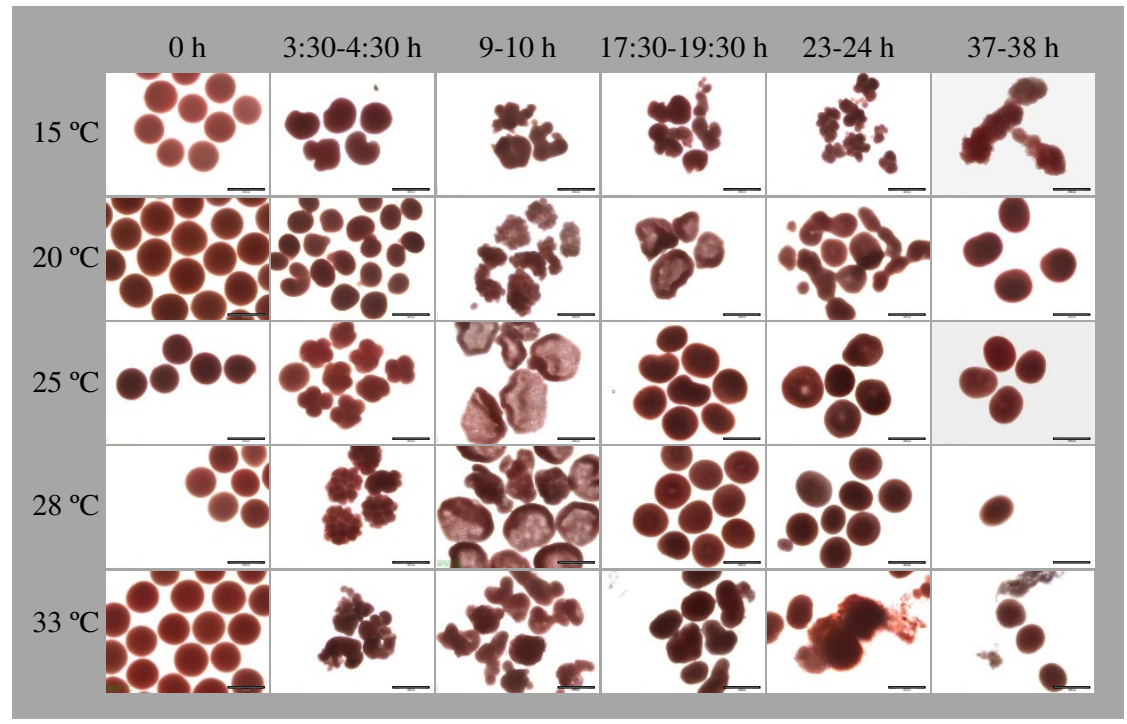

Figure 6 Time series photos showing the effect of temperature on embryonic development in A. muricata at PMBRC, Penghu, Taiwan. Columns represent the different times that elapsed from fertilization $(0 \mathrm{~h})$ to motility. Rows represent temperature treatments of $15,20,25,28$, and $33^{\circ} \mathrm{C} . \mathrm{Scale}$ bar $=500 \mu \mathrm{m}$.

of development, particularly at lower temperatures $\left(15\right.$ and $20^{\circ} \mathrm{C}$; Fig. 9 A, B, C, Table 4). Such variability across different crosses might also be due to phenotype. For example, there were higher success rates in certain parent crosses when fertilizing Acropora palmata under stressful conditions ${ }^{42}$. Future studies on this aspect will give important insight as to how genotypic and phenotypic characters influence the tolerance of corals to varying temperatures during their early life stages.

Due to their broad latitudinal distribution and associated temperature ranges, some reef communities may have a built-in adaptive capacity to accommodate temperature increases ${ }^{8}$. The water temperature increases slowly in Kochi from winter to summer compared to Penghu (Fig. 3). Although the summer average seawater temperature is similar $\left(\sim 26-28^{\circ} \mathrm{C}\right)$ at both locations, it might be that since adults are more accustomed to longer periods of low seawater temperatures, early coral life stages tolerate colder temperatures much better in temperate areas like Kochi. At $15^{\circ} \mathrm{C}$, A. hyacinthus at $\mathrm{BIK}$ had a $100 \%$ fertilization rate (Fig. 5, Fig. $9 \mathrm{C}$ ), and at $20^{\circ} \mathrm{C}$ the variation between crosses was lower in comparison to A. hyacinthus from PMBRC (Fig. 5, Fig. 9 B). Upon exposure to high temperature $\left(33^{\circ} \mathrm{C}\right)$, early stages of $A$. hyacinthus from PMBRC fared better than those from BIK (Fig. 5, Fig. 9 A, B). The physiological and life history traits $^{62}$ and exposure of adult corals to historical temperature ${ }^{63,64}$ could play a role in determining the thermal limits of early life stages ${ }^{2,4,9}$. Nevertheless, organisms will often be concurrently exposed to multiple stresses in addition to fluctuations in seawater temperature, including anthropogenic stresses ${ }^{8}$. This will add to the challenges that corals must endure in their early stages of development, and only time will tell if they can overcome this challenge through adaptive and acclimative mechanisms such as changes in larval dispersal and recruitment success, shifts in community structure, and range extensions through migration ${ }^{8}$.

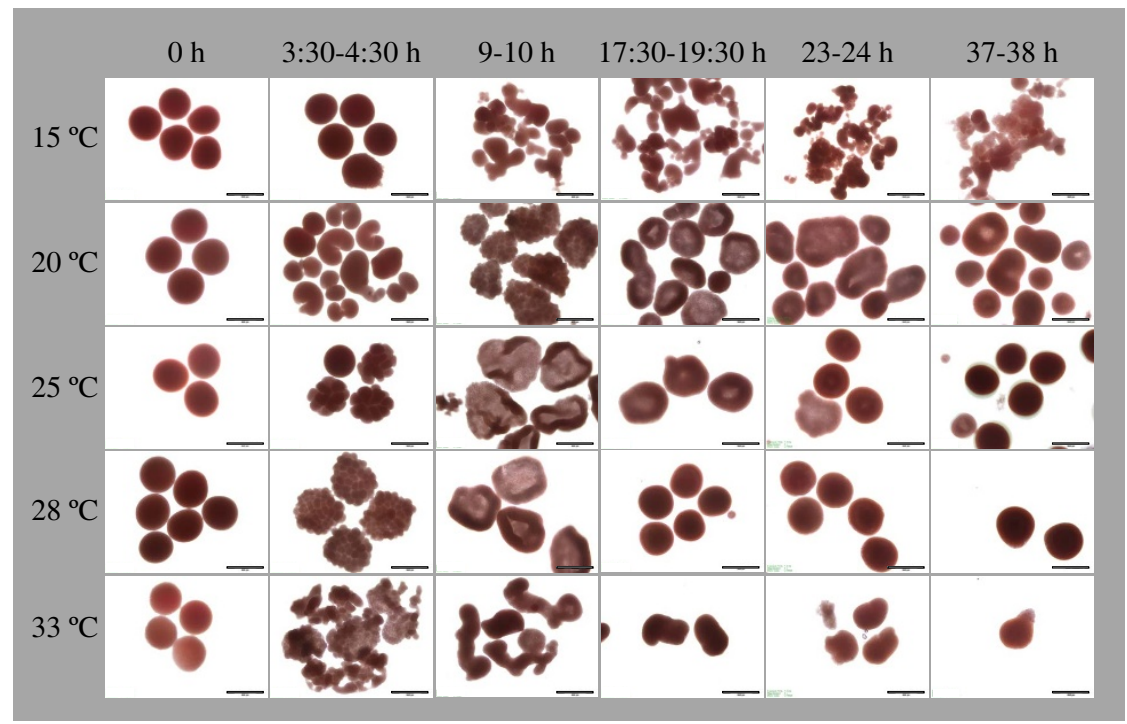

Figure $7 \mid$ Time series photos showing the effects of temperature on embryonic development in A. hyacinthus at PMBRC, Penghu, Taiwan. Columns represent the different times elapsing from fertilization $(0 \mathrm{~h})$ to motility. Rows represent temperature treatments of $15,20,25,28$, and $33^{\circ} \mathrm{C} . \mathrm{Scale}$ bar $=$ $500 \mu \mathrm{m}$. 


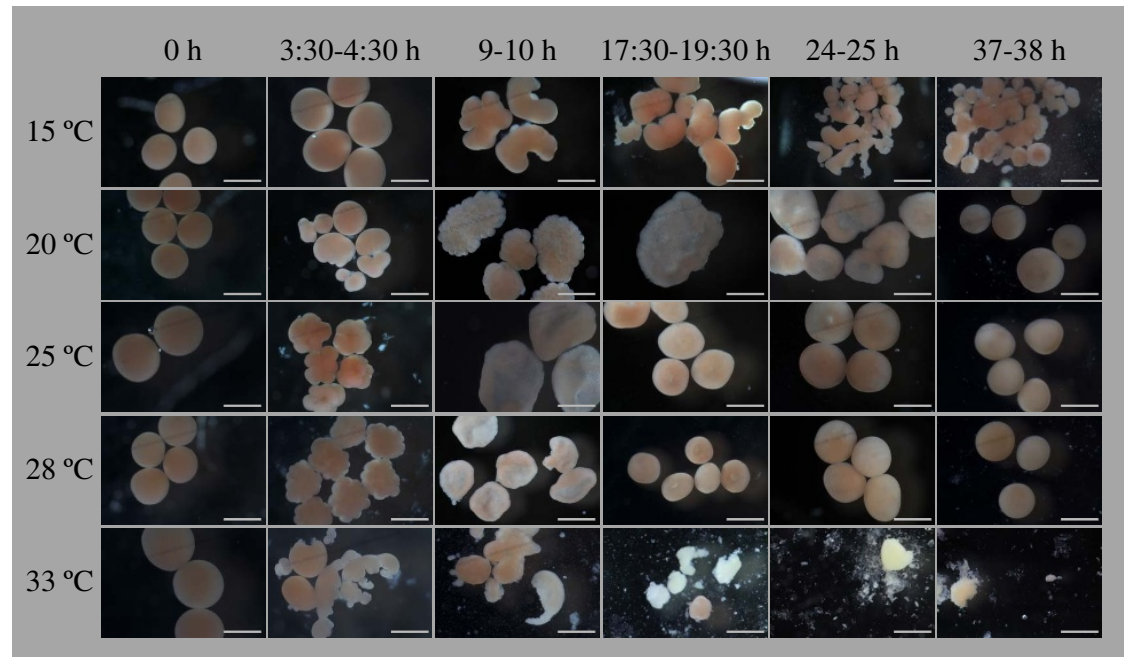

Figure 8 Time series photos showing the effects of temperature on embryonic development in A. hyacinthus at BIK, Nishidomari, Otsuki, Japan. Columns represent the different times elapsing from fertilization $(0 \mathrm{~h})$ to motility. Rows represent temperature treatments of $15,20,25,28$, and $33^{\circ} \mathrm{C}$. Scale bar $=500 \mu \mathrm{m}$.

Our study clearly shows that corals, like other marine invertebrates, do have a wide temperature tolerance range $\left(15-33^{\circ} \mathrm{C}\right.$ in the present study) for successful gamete fertilization. Also, there is a latitudinal difference in response to temperature, so local adaptations to prevailing seawater temperatures might play an important role ${ }^{36}$. Recent studies on climate change-induced ocean warming have indicated seasonal abnormal seawater temperature fluctuations leading to episodic high or low seawater temperatures in summer and winter ${ }^{33,65,66}$. Moreover, the average seawater temperature is getting warmer in the summer months in tropical, sub-tropical, and temperate seas ${ }^{67-69}$. As a result of this, we predict that the problem will be in the response of pre-motile developmental stages to seawater temperature stress. This is particularly true for broadcast-spawning corals, because egg fertilization occurs in the water column followed by larval development that occurs in direct contact with warm water ${ }^{41}$. It is believed that stressors like ocean warming will have carryover effects from one life history stage to another, creating bottlenecks for populations that have sub-lethal or lethal consequences ${ }^{41}$. Recent studies have shown that temperature stress can also influence circadian rhythms, thereby affecting the behavior, physiology, and metabolism of bacteria, fungi, plants, and animals ${ }^{70,71}$. Such impacts on circadian rhythms during early developmental stages in corals could also hamper their survival. The implication that stresses like high seawater temperatures may play a role in future coral survival, plus the fact that the narrow window of opportunity for successful development is fast closing due to the rapidity of the changes in seawater temperature, means that corals will have to find effective

Table 2 | Inter-location comparison of the responses of $A$. hyacinthus to seawater temperature stress at PMBRC and BIK. Hy_P $=A$. hyacinthus from PMBRC, Hy_B $=A$. hyacinthus from BIK

\begin{tabular}{lccccc} 
& $15^{\circ} \mathrm{C}$ & $20^{\circ} \mathrm{C}$ & $25^{\circ} \mathrm{C}$ & $28^{\circ} \mathrm{C}$ & $33^{\circ} \mathrm{C}$ \\
\hline $\begin{array}{l}\text { Fertilization } \\
\text { Hy_P vs. Hy_B }\end{array}$ & ns & ns & ns & ns & $\mathbf{0 . 0 0 0 1}$ \\
$\begin{array}{l}\text { Prawn chip } \\
\text { Hy_Pvs. Hy_B } \\
\text { Donut } \\
\text { Hy_P vs. Hy_B }\end{array}$ & ns & ns & ns & ns & $\mathbf{0 . 0 0 1}$ \\
$\begin{array}{l}\text { Pear } \\
\text { Hy_P vs. Hy_B }\end{array}$ & ns & ns & ns & ns & ns \\
\hline
\end{tabular}

adaptive strategies quickly, as time is running out for their continued survival.

\section{Methods}

Study site and environmental conditions. The experiments were conducted at Penghu Marine Biology Research Centre (PMBRC), Penghu, Taiwan (subtropical, N023.31, E119.33) in May 2012 and at the Biological Institute on Kuroshio (BIK), Otsuki, Kochi-Japan (temperate, N032.46, E132.43) in August 2012 (Fig. 1). The locations from which the coral colonies were collected at PMBRC (Acropora hyacinthus and A. muricata), Aiman (N023.33, E119.38), and Chinwan Inner Bay (N023.31, E119.33) are characterized by shallow patchy coral communities at a distance of $\sim 10 \mathrm{~m}$ from shore. The distance between Aiman and Chinawan Inner Bay is $5 \mathrm{~km}$. At BIK, experimental colonies (Acropora hyacinthus) were collected from the adjacent coral community at Nishidomari, where coral communities are located on patch rocks at a distance of $\sim 10 \mathrm{~m}$ from the shore. Coral colonies were collected from 3-4 m depths at all locations. Temperature loggers $\left(\mathrm{HOBO}^{\odot}\right.$ pendant, Onset Corp, USA) were maintained at the two locations from December 2011January 2013 at a depth of $4 \mathrm{~m}$ near the coral colonies to document the differences in seawater temperatures.

Sample collection. Approximately one week prior to predicted spawning dates ${ }^{72}$ at PMBRC, colonies were collected and deposited in tagged individual buckets in tanks with continuous flows of seawater and aeration. Seawater flow in the tanks was stopped daily after sunset ( $c a .1830 \mathrm{hrs}$ ) throughout the spawning period. If no spawning was observed on any particular day, seawater flow was restored after 2230 hrs. At BIK, spawning was observed in situ by SCUBA diving every night from $1900 \mathrm{hrs}$ during predicted spawning dates ${ }^{73}$. On the peak spawning day, colonies with maximum egg-sperm bundles (as seen visually underwater) were collected $1 \mathrm{~h}$ before spawning, transported to BIK, and placed in individual $100 \mathrm{~L}$ containers with aeration. A. muricata spawning was observed and their bundles collected at PMBRC on 11 May, five days after the full moon, and on 13 May for A. hyacinthus, seven days after the full moon. Collections at BIK for A. hyacinthus occurred on 7 August, five

Table 3 | Intra-location comparison of the responses by $A$. muricata and $A$. hyacinthus to seawater temperature stress at PMBRC. $\mathrm{Mu} \mathrm{P}=\mathrm{A}$ muricata from PMBRC, Hy_P $=A$. hyacinthus from $\mathrm{PMBRC}$

\begin{tabular}{lccccc} 
& $15^{\circ} \mathrm{C}$ & $20^{\circ} \mathrm{C}$ & $25^{\circ} \mathrm{C}$ & $28^{\circ} \mathrm{C}$ & $33^{\circ} \mathrm{C}$ \\
\hline $\begin{array}{l}\text { Fertilization } \\
\begin{array}{l}\text { Mu_Pvs. Hy_P } \\
\text { Prawn chip }\end{array}\end{array}$ & $\mathbf{0 . 0 1}$ & ns & ns & ns & ns \\
$\begin{array}{l}\text { Mu_Pvs. Hy_P } \\
\text { Donut }\end{array}$ & ns & ns & ns & ns & ns \\
$\begin{array}{l}\text { Mu_Pvs. Hy_P } \\
\text { Pear }\end{array}$ & ns & ns & ns & ns & ns \\
Mu_Pvs. Hy_P & ns & ns & ns & ns & ns \\
\hline
\end{tabular}



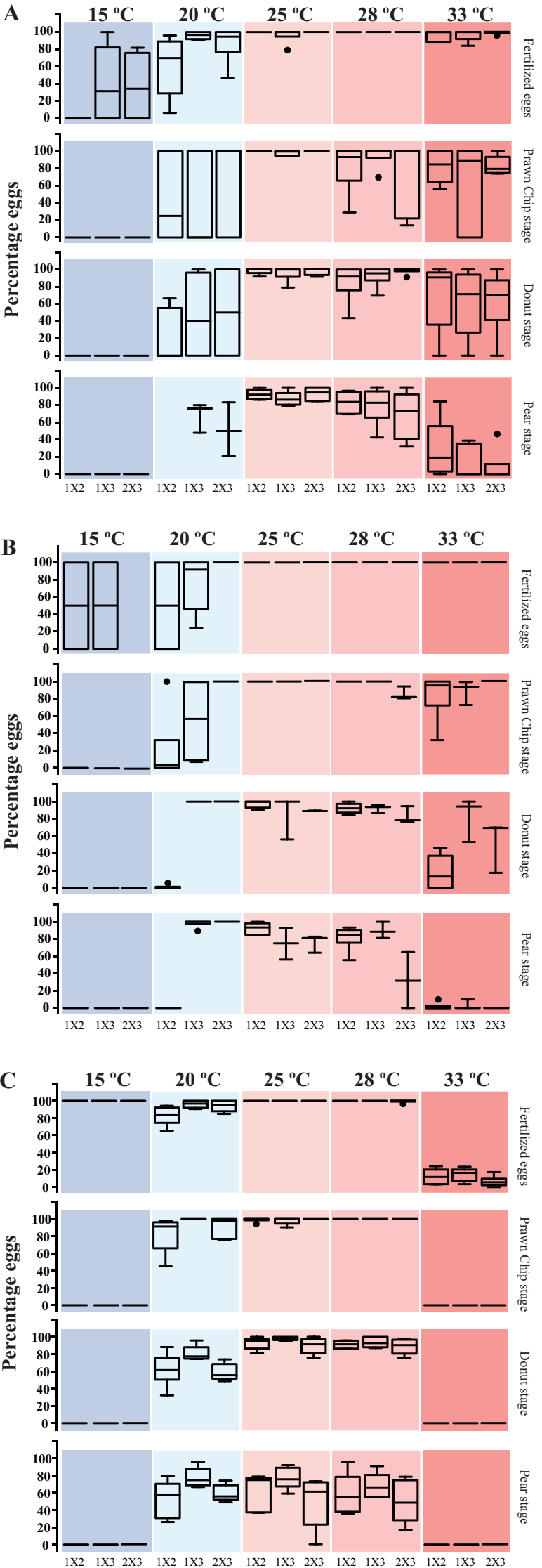

Between colony cross

Figure 9 Quantitative data for inter-cross fertilization for the three trials separately: (A) A. muricata in PMBRC, (B) A. hyacinthus in PMBRC, and (C) A. hyacinthus in BIK at different temperature treatments $\left(15,20,25,28\right.$, and $33^{\circ} \mathrm{C}$ columns are depicted in different colors). The crosses are: $1 \mathrm{X} 2=$ cross between colonies 1 and 2, $1 \mathrm{X} 3=$ cross between colonies 1 and 3 and $2 X 3=$ cross between colonies 2 and 3 . The box indicates the 25th and 75th percentiles, and the line within the box marks the median. Whiskers above and below the box indicate the 10th and 90th percentiles.

days after the full moon. A. muricata spawning was not observed during the survey period at BIK. Gamete bundles released from three colonies of each species onto the surface of the water in the buckets/containers were separately scooped up using tagged plastic cups and brought back to the laboratory for crossing experiments.

It was not possible to perform the same type of trial for A. muricata in both localities due to its overlap in spawning times in 2012. We tried to carry out the same experiment for A. muricata in 2013, but the experiment was unsuccessful due to gamete fertilization failure during two successive trials in June of that year.

Experimental design and crossing experiments. Crossing experiments for the three trials were performed by the same individuals ( $1^{\text {st }}$ and $2^{\text {nd }}$ authors) at both locations using the same experimental setup by shipping it to BIK after experiments were completed at PMBRC. Three colonies from each species were chosen for crossing and temperature stress experiment (Fig. 2). Bundles were filtered through a $120 \mu \mathrm{m}$ plankton mesh to separate eggs and sperm, and aliquots of eggs and sperm were collected for density counts. A $9 \mu \mathrm{l}$ aliquot of sperm was fixed with $1 \mu \mathrm{l}$ of $2 \%$ formalin and the sperm counted in a haemocytometer using an Olympus microscope

Table 4 | Inter-cross comparison of the responses between $A$. muricata and $A$. hyacinthus to seawater temperature stress at PMBRC and $\mathrm{BIK}$. Values in black $=A$. muricata (PMBRC), brown $=A$. hyacinthus (PMBRC), green $=A$. hyacinthus (BIK)

$15^{\circ} \mathrm{C} \quad 20^{\circ} \mathrm{C} \quad 25^{\circ} \mathrm{C} \quad 28^{\circ} \mathrm{C} \quad 33^{\circ} \mathrm{C}$

\section{Fertilization}

Cross $1 \times 2$ vs. Cross 1X3

Cross $1 \times 2$ vs. Cross $2 \times 3$

Cross $1 \times 3$ vs. Cross $2 \times 3$

$\begin{array}{ccc}0.001 & 0.002 & n s \\ n s & n s & n s \\ n s & 0.001 & n s \\ 0.001 & 0.02 & n s \\ 0.02 & 0.02 & n s \\ n s & 0.001 & n s \\ n s & n s & n s \\ 0.02 & n s & n s\end{array}$

Prawn chip

Cross $1 \times 2$ vs. Cross $1 \times 3$

Cross $1 X 2$ vs. Cross $2 \times 3$

Cross $1 X 3$ vs. Cross $2 \times 3$

Donut

Cross $1 \times 2$ vs. Cross $1 \times 3$

Cross $1 X 2$ vs. Cross $2 X 3$

\begin{tabular}{lllll} 
ns & \multicolumn{1}{c}{$\mathrm{ns}$} & $\mathrm{ns}$ & $\mathrm{ns}$ & $\mathrm{ns}$ \\
$\mathrm{ns}$ & 0.005 & $\mathrm{~ns}$ & $\mathrm{~ns}$ & $\mathrm{~ns}$ \\
$\mathrm{~ns}$ & 0.001 & $\mathrm{~ns}$ & $\mathrm{~ns}$ & $\mathrm{~ns}$ \\
$\mathrm{~ns}$ & $\mathrm{~ns}$ & $\mathrm{~ns}$ & $\mathrm{~ns}$ & $\mathrm{~ns}$ \\
$\mathrm{~ns}$ & 0.001 & $\mathrm{~ns}$ & $\mathrm{~ns}$ & $\mathrm{~ns}$ \\
$\mathrm{~ns}$ & 0.01 & $\mathrm{~ns}$ & $\mathrm{~ns}$ & $\mathrm{~ns}$ \\
$\mathrm{~ns}$ & 0.05 & $\mathrm{~ns}$ & $\mathrm{~ns}$ & $\mathrm{~ns}$ \\
$\mathrm{~ns}$ & 0.005 & $\mathrm{~ns}$ & $\mathrm{~ns}$ & $\mathrm{~ns}$ \\
$\mathrm{~ns}$ & 0.01 & $\mathrm{~ns}$ & $\mathrm{~ns}$ & $\mathrm{~ns}$ \\
& & & & \\
$\mathrm{~ns}$ & $\mathrm{~ns}$ & $\mathrm{~ns}$ & $\mathrm{~ns}$ & $\mathrm{~ns}$ \\
$\mathrm{~ns}$ & 0.001 & $\mathrm{~ns}$ & $\mathrm{~ns}$ & 0.001 \\
$\mathrm{~ns}$ & 0.001 & $\mathrm{~ns}$ & $\mathrm{~ns}$ & $\mathrm{~ns}$ \\
$\mathrm{~ns}$ & 0.06 & $\mathrm{~ns}$ & $\mathrm{~ns}$ & $\mathrm{~ns}$ \\
$\mathrm{~ns}$ & 0.001 & $\mathrm{~ns}$ & $\mathrm{~ns}$ & 0.001 \\
$\mathrm{~ns}$ & $\mathrm{~ns}$ & $\mathrm{~ns}$ & $\mathrm{~ns}$ & $\mathrm{~ns}$ \\
$\mathrm{~ns}$ & $\mathrm{~ns}$ & $\mathrm{~ns}$ & $\mathrm{~ns}$ & $\mathrm{~ns}$ \\
$\mathrm{~ns}$ & $\mathrm{~ns}$ & $\mathrm{~ns}$ & $\mathrm{~ns}$ & 0.003 \\
$\mathrm{~ns}$ & 0.001 & 0.03 & $\mathrm{~ns}$ & $\mathrm{~ns}$
\end{tabular}

Pear

Cross $1 \times 2$ vs. Cross $1 \times 3$

Cross $1 \times 2$ vs. Cross $2 \times 3$

Cross $1 \times 3$ vs. Cross $2 \times 3$

\begin{tabular}{|c|c|c|c|}
\hline ns & ns & ns & ns \\
\hline 0.001 & 0.01 & ns & ns \\
\hline ns & ns & ns & ns \\
\hline ns & $\mathrm{ns}$ & 0.1 & 0.03 \\
\hline 0.001 & 0.01 & 0.001 & ns \\
\hline ns & ns & ns & ns \\
\hline ns & ns & ns & ns \\
\hline ns & ns & 0.001 & ns \\
\hline 0.03 & 0.003 & 0.03 & ns \\
\hline
\end{tabular}


BX43 (Olympus Corporation, Tokyo, Japan) to obtain the correct concentration. Sperm density was diluted $\left(10^{5}-10^{6} \mathrm{ml}^{-1}\right)$ for the crossing experiment ${ }^{72}$. Eggs were washed ten times in sperm-free filtered seawater in order to prevent self-fertilization. This water was collected some hours before spawning to guarantee the absence of sperm from early spawning corals. Three colonies from each species were crossed to obtain a total of nine separate crosses, including self-fertilization crosses (e.g., egg colony $1 \times$ sperm colony 2 , egg colony $1 \times$ sperm colony 3 ) (Fig. 2 ). The control treatment contained only eggs in filtered seawater (Fig. 2). Approximately 20 washed eggs were counted using a glass Pasteur pipette and placed in separate wells of a 12well culture plate with $4 \mathrm{ml}$ of diluted sperm $\left(10^{6} \mathrm{ml}^{-1}\right)$. Three replicates were established for all egg-sperm crosses, with a total of 18 repetitions for each trial (i.e., for each species and location). Three replicates of the self-fertilization treatments and controls were established for each colony.

After mixing the different egg-sperm combinations, culture plates were placed in plastic tanks with different seawater temperatures: $15,20,25,28$, and $33^{\circ} \mathrm{C}$. The temperature in each tank was controlled with aquarium coolers/heaters (HAILEA HC-150A, Guangdong Hailea Group Co., Ltd, China) and metal-halide lamps with $12 \mathrm{~h}$ night/day cycles providing light. The temperature in each tank was recorded throughout the experimental period with temperature loggers (HOBO, Pendant ${ }^{\mathrm{TM}}$ USA) set to record water temperature at $10 \mathrm{~min}$ intervals. Gametes from separate colonies were also crossed in cylindrical glass jars at ambient temperature to detect the timing of the developmental cycle without any temperature treatment (Fig. 4). To prevent decreases in water quality due to degrading unfertilized gametes, water was changed in each well using a plastic Pasteur pipette after the fertilization stage and subsequently at $5,10,24$, and $48 \mathrm{~h}$ of the developmental cycle.

Fertilization and development. Developmental stages were observed from the crossings at $0,2,8,17,24$, and $37 \mathrm{~h}$ following the developmental cycle ${ }^{51,52}$. Photos were taken at each stage using an Olympus microscope with an Olympus DP72 CCD camera (Olympus Corporation, Tokyo, Japan) and a Canon 7D camera (Figs. 6, 7, 8), and survival rates were observed under an Olympus CX31 microscope (Olympus Corporation, Tokyo, Japan). Fertilization success, the percentage of cells clearly reaching every step of the normal cycle in non-aberrant shape (prawn chip, donuts, and pear, per ${ }^{51}$ ) (Fig. 4), and the rates of aberrant development (Fig. 6, 7, 8) were recorded. Cycle time was established by performing fertilizations at ambient temperature (Fig. 4). The experiment was conducted until the appearance of the first motile stage (pear-shaped larvae).

Data analysis. The quantitative data comprising the percentages of eggs fertilized and their subsequent development into prawn chips, donut, and pear stages were plotted for each temperature treatment as Tukey box plots. For each developmental stage, the data from six crosses (crossing between three eggs and three sperms), with a total of 18 replicate values (self-cross and control were excluded since they were not fertilized) in each temperature column were compared to each other by a one-way ANOVA to see if there were any significant differences between column values. A nonparametric Kruskal-Wallis test without assuming Gaussian distribution was carried out with a Dunn's post-test to compare all pairs of columns. This analysis was carried out for inter- and intraspecies differences during different stages of development. Furthermore, we carried out a similar analysis for the inter-treatment comparison for the trials between the two locations. An analysis of the repetition effect on the variability within each trial was performed as well to detect possible genotypic effects on performance. All the graphs and statistical analyses were performed using GraphPad Prism version 6.0 for Mac OS X, GraphPad Software, San Diego California USA.

1. Greenwood, P. J. \& Bennet, T. Some effects of temperature-salinity combinations on the early development of the sea urchin Parechinus angulosus (Leske). fertilization. J. Exp. Mar. Biol. Ecol. 51, 119-131 (1981).

2. Byrne, M. et al. Temperature, but not $\mathrm{pH}$, compromises sea urchin fertilization and early development under near-future climate change scenarios. Proc R Soc. B. 276, 1883-1888 (2009)

3. Brennand, H. S., Soars, N., Dworjanyn, S. A., Davis, A. R. \& Byrne, M. Impact of ocean warming and acidification on larval development and calcification in the sea urchin Tripneustes gratilla. PLoS ONE 5(6), e11372 (2010).

4. Byrne, M. Impact of ocean warming and ocean acidification on marine invertebrate life history stages: vulnerabilities and potential for persistence in a changing ocean. Oceanogr. Mar. Biol. Annu. Rev. 49, 1-42 (2011).

5. Byrne, M. Global change ecotoxicology: Identification of early life history bottlenecks in marine invertebrates, variable species responses and variable experimental approaches. Mar. Environ. Res. 76, 3-15 (2012).

6. Byrne, M., Gonzalez-Bernat, M., Doo, S. \& Foo, S. Effects of ocean warming and acidification on embryos and non-calcifying larvae of the invasive sea star Patiriella regularis. Mar. Ecol. Prog. Ser. 473, 235-246 (2013).

7. Przeslawski, R. \& Davis, A. R. Does spawning behavior minimize exposure to environmental stressors for encapsulated gastropod embryos on rocky shores? Mar. Biol. 152, 991-1002 (2007).

8. Przeslawski, R., Ahyong, S., Byrne, M., Wörheide, G. \& Hutchings, P. Beyond corals and fish: the effects of climate change on noncoral benthic invertebrates of tropical reefs. Global Change Biol. 14, 2773-2795 (2008).
9. Pineda, M. C. et al. Tough adults, frail babies: an analysis of stress sensitivity across early life-history stages of widely introduced marine invertebrates. PLOS ONE 7, e46672 (2012).

10. Bassim, K. M., Sammarco, P. W. \& Snell, T. L. Effects of temperature on success of (self and non-self) fertilization and embryo- genesis in Diploria strigosa (Cnidaria, Scleractinia). Mar. Biol. 140, 479-488 (2002).

11. Chua, C. M., Leggat, W., Moya, A. \& Baird, A. H. Temperature affects the early life history stages of corals more than near future ocean acidification. Mar. Ecol. Prog. Ser. 475, 85-92 (2013).

12. Negri, A., Marshall, P. \& Heyward, A. Differing effects of thermal stress on coral fertilization and early embryogenesis in four Indo Pacific species. Coral Reefs 26, 759-763 (2007).

13. Fitt, W., Brown, B., Warner, M. \& Dunne, R. Coral bleaching: interpretation of thermal tolerance limits and thermal thresholds in tropical corals. Coral Reefs 20, 51-65 (2001)

14. Riegl, B., Purkis, S., Al-Cibahy, A. \& Abdel-Moati, M. Present Limits to HeatAdaptability in Corals and Population-Level Responses to Climate Extremes. PLOS ONE 6, e24802 (2011).

15. Monaco, C. J. \& Helmuth, B. Tipping points, thresholds and the keystone role of physiology in marine climate change research. Adv. Mar. Biol. 60, 123-160 (2011).

16. Donelson, J. M. \& Munday, P. L. Thermal sensitivity does not determine acclimation capacity for a tropical reef fish. J. Anim. Ecol. 81, 1126-1131 (2012).

17. Woolsey, E. S., Byrne, M. \& Baird, A. H. The effects of temperature on embryonic development and larval survival in two scleractinian corals. Mar. Ecol. Prog. Ser. 493, 179-184 (2013).

18. Edmunds, P. J., Gates, R. D. \& Gleason, D. F. The biology of larvae from the reef coral Porites astreoides, and their response to temperature disturbances. Mar. Biol. 139, 981-989 (2001).

19. Edmunds, P. J. The effect of sub-lethal increases in temperature on the growth and population trajectories of three scleractinian corals on the southern Great Barrier Reef. Oecologia 146, 350-364 (2005).

20. Bassim, K. M. \& Sammarco, P. W. Effects of temperature and ammonium on larval development and survivorship in a scleractinian coral (Diploria strigosa). Mar. Biol. 142, 241-252 (2003).

21. Baird, A. H. et al. Temperature tolerance of symbiotic and non-symbiotic coral larvae. Proc 10th Int Coral Reef Symp, Okinawa Convention Center, Okinawa, Japan. Japanese Coral Reef Society 1, 38-42 (2006).

22. Nozawa, Y. \& Harrison, P. L. Effects of elevated temperature on larval settlement and post-settlement survival in scleractinian corals, Acropora solitaryensis and Favites chinensis. Mar. Biol. 152, 1181-1185 (2007).

23. Randall, C. J. \& Szmant, A. M. Elevated temperature affects development, survivorship, and settlement of the elkhorn coral, Acropora palmata (Lamarck 1816). Biol. Bull. 217, 269-282 (2009).

24. Coles, S. L. \& Brown, B. E. Coral bleaching - capacity for acclimatization and adaptation. Adv. Mar. Biol. 46, 183-223 (2003).

25. Ayre, D. \& Hughes, T. Climate change, genotypic diversity and gene flow in reefbuilding corals. Ecol. Lett. 7, 273-278 (2004).

26. Baker, A., Starger, C., McClanahan, T. \& Glynn, P. Coral reefs: corals' adaptive response to climate change. Nature 430, 741 (2004).

27. Rowan, R. Coral bleaching: thermal adaptation in reef coral symbionts. Nature 430, 742-742 (2004).

28. Berkelmans, R. \& Van Oppen, M. J. H. The role of zooxanthellae in the thermal tolerance of corals: A "nugget of hope" for coral reefs in an era of climate change. Proc. R. Soc. B. 273, 2305-2312 (2006).

29. Shaish, L., Abelson, A. \& Rinkevich, B. How plastic can phenotypic plasticity be? The branching coral Stylophora pistillata as a model system. PLoS ONE 2, e644 (2007).

30. Strychar, K. B. \& Sammarco, P. W. 2009. Exaptation in corals to high seawater temperatures: Low concentrations of apoptotic and necrotic cells in host coral tissue under bleaching conditions. J. Exp. Mar. Biol. Ecol. 369, 31-42.

31. Hennige, S., Smith, D. \& Walsh, S. Acclimation and adaptation of scleractinian coral communities along environmental gradients within an Indonesian reef system. J. Exp. Mar. Biol. Ecol. 391, 143-152 (2010).

32. Barshis, D. J. et al. Protein expression and genetic structure of the coral Porites lobata in an environmentally extreme Samoan back reef: does host genotype limit phenotypic plasticity? Mol. Ecol. 19, 1705-1720 (2010)

33. Oliver, T. A. \& Palumbi, S. R. Do fluctuating temperature environments elevate coral thermal tolerance? Coral Reefs 30, 429-440 (2011).

34. Bellantuono, A. J., Hoegh-Guldberg, O. \& Rodriguez-Lanetty, M. Resistance to thermal stress in corals without changes in symbiont composition. Proc. R. Soc. B. 279, 1100-1107 (2012).

35. Keshavmurthy, S. et al. Symbiont communities and host genetic structure of the brain coral Platygyra verweyi, at the outlet of a nuclear power plant and adjacent areas. Mol. Ecol. 21, 4393-4407 (2012).

36. Howells, E. J. et al. Coral thermal tolerance shaped by local adaptation of photosymbionts. Nature Clim. Change 2, 116-120 (2012).

37. Edmunds, P. J., Cumbo, V. \& Fan, T. Y. Effects of temperature on the respiration of brooded larvae from tropical reef corals. J. exp. biol. 214, 2783-2790 (2011).

38. Heyward, A. J. \& Negri, A. P. Plasticity of larval pre-competency in response to temperature: observations on multiple broadcast spawning coral species. Coral Reefs 29, 631-636 (2010). 
39. Anlauf, H., D'Croz, L. \& O'Dea, A. A corrosive concoction: The combined effects of ocean warming and acidification on the early growth of a stony coral are multiplicative. J. Exp. Mar. Biol. Ecol. 397, 13-20 (2011).

40. Negri, A. P. \& Hoogenboom, M. O. Water contamination reduces the tolerance of coral larvae to thermal stress. PLoS ONE 6, e19703 (2011).

41. Ross, P. M., Parker, L., O'Connor, W. A. \& Bailey, E. A. The impact of ocean acidification on reproduction, early development and settlement of marine organisms. Water 3, 1005-1030 (2011).

42. Baums, I. B. et al. Genotypic variation influences reproductive success and thermal stress tolerance in the reef building coral, Acropora palmata. Coral Reefs 32, 703-717 (2013).

43. Okubo, N. \& Motokawa, T. Embryogenesis in reef-building coral Acropora spp. Zool Sci. 24, 1169-1177 (2007).

44. Brown, B. E. Coral bleaching: causes and consequences. Coral Reefs 16, 129-138 (1997)

45. Glynn, P. W. Coral reef bleaching: facts, hypotheses and implications. Glob. Change Biol. 2, 495-509 (1996).

46. Hoegh-Guldberg, O. Climate change, coral bleaching and the future of the world's coral reefs. Mar. Freshw. Res. 50, 839-866 (1999).

47. Denis, V. et al. Coverage, diversity, and functionality of a high-latitude coral community (Tatsukushi, Shikoku Island, Japan). PLoS ONE 8, e54330 (2013).

48. Coles, S. L. \& Riegl, B. M. Thermal tolerances of reef corals in the Gulf: a review of the potential for increasing coral survival and adaptation to climate change through assisted translocation. Mar. Pollut. Bull. 72, 323-332 (2013).

49. Babcock, R. C. \& Heyward, A. J. Larval development of certain gamete- spawning scleractinian corals. Coral Reefs 5, 111-116 (1986).

50. Hayashibara, T., Ohieke, S. \& Kakinuma, Y. Embryonic and larval development and planula metamorphosis of four gamete-spawning Acropora (Anthozoa, Scleractinia). Proc 8th Int Coral Reef Symp, University of Panaman and Smithsonian Tropical Institute, Panama City. 2, 1231-1236 (1997).

51. Miller, D. J. \& Ball, E. E. The coral Acropora: what it can contribute to our knowledge of metazoan evolution and the evolution of developmental processes. BioEssays 22, 291-296 (2000).

52. Keshavmurthy, S. et al. Larval development of fertilized "pseudo-gynodioecious" eggs suggests a sexual pattern of gynodioecy in Galaxea fascicularis (Scleractinia: Euphyllidae). Zool. Stud. 51, 143-149 (2012).

53. Solomon, S. D. et al. The Physical Science Basis. Contribution of Working Group I to the Fourth Assessment Report of the Intergovernmental Panel of Climate Change. (Cambridge Univ. Press, Cambridge, 2007).

54. Johnson, L. G. \& Babcock, R. C. Temperature and the larval ecology of the crownof-thorns starfish, Acanthaster planci. Biol. Bull. 168, 419-443 (1994).

55. Parker, L. M., Ross, P. M. \& O’Connor, W. A. Comparing the effect of elevated $\mathrm{pCO}_{2}$ and temperature on the fertilization and early development of two species of oysters. Mar. Biol. 157, 2435-52 (2010).

56. Nozawa, Y. Annual variation in the timing of coral spawning in a high-latitude environment: Influence of temperature. Biol Bull. 222, 192-202 (2012).

57. Bates, W. R. Environmental factors affecting reproduction and development in ascidians and other protochordates. Can. Journ. Zool. 83, 51-61 (2005).

58. De Putron, S. J. \& Ryland, J. S. Effect of seawater temperature on reproductive seasonality and fecundity of Pseudoplexaura porosa (Cnidaria: Octocorallia): latitudinal variation in Caribbean gorgonian reproduction Invert. Biol. 128, 213-222 (2009).

59. Yamano, H., Sugihara, K. \& Nomura, K. Rapid poleward range expansion of tropical reef corals in response to rising sea surface temperatures. Geophys. Res. Lett. 38, L04601; DOI:10.1029/2010GL046474 (2011).

60. Yara, Y. et al. Projection and uncertainty of the poleward range expansion of coral habitats in response to sea surface temperature warming: a multiple climate model study. Galaxea, Journal of Coral Reef Studies 13, 1-10 (2012).

61. Keshavmurthy, S. et al. Can resistant coral-Symbiodinium associations enable coral communities to survive climate change? A study of a site exposed to longterm hot water input. PeerJ 2, e327; DOI 10.7717/peerj.327 (2014).

62. Darling, E. S., Alvarez-Filip, L., Oliver, T. A., McClanahan, T. R. \& Cote, I. M. Evaluating life-history strategies of reef corals from species traits. Ecol. Lett. 15, 1378-1386 (2012).

63. Carilli, J., Donner, S. D. \& Hartmann, A. C. Historical temperature variability affects coral response to heat stress. PLoS ONE 7(3), e34418 (2012).
64. Howells, E. J., Berkelmans, R., van Oppen, M. J. H., Willis, B. L. \& Bay, L. K. Historical thermal regimes define limits to coral acclimatization. Ecology 94, 1078-1088 (2013).

65. Donner, S. D. Coping with commitment: projected thermal stress on coral reefs under different future scenarios. PLoS ONE 4, e5712 (2009).

66. Eakin, C. et al. Caribbean corals in crisis: Record thermal stress, bleaching, and mortality in 2005. PLoS ONE 5, el3969 (2010).

67. Vose, R. S., Easterling, D. R. \& Gleason, B. Maximum and minimum temperature trends for the globe: An update through 2004. Geophys. Res. Lett 32, L23822; DOI:10.1029/2005GL024379 (2005).

68. Hoegh-Guldberg, O. et al. Coral reefs under rapid climate change and ocean acidification. Science 318, 1737-1742 (2007).

69. Traill, L. W., Lim, M. L. M., Sodhi, N. S. \& Bradshaw, C. J. A. Mechanisms driving change: altered species interactions and ecosystem function through global warming. J. Anim. Ecol. 79, 937-947 (2010).

70. Dodd, A. N. et al. Plant circadian clocks increase photosynthesis, growth, survival, and competitive advantage. Science 309, 630-633 (2005).

71. Bass, J. Circadian topology of metabolism. Nature 491, 348-356 (2012).

72. Willis, B. L., Babcock, R. C., Harrison, P. L. \& Wallace, C. C. Experimental hybridization and breeding incompatibilities within the mating systems of mass spawning reef corals. Coral Reefs 16, S53-S65 (1997).

73. Mezaki, T. et al. Spawning patterns of high latitude scleractinian corals from 2002 to 2006 at Nishidomari, Otsuki, Japan. (in Japanese with English abstract) Kuroshio Biosphere 3, 33-47 (2007).

74. Gilmour, J. Experimental investigation into the effects of suspended sediment on fertilisation, larval survival and settlement in a scleractinian coral. Mar. Biol. 135, 451-462 (1999)

75. Wellington, G. M. \& Fitt, W. K. Influence of UV radiation on the survival of larvae from broadcast-spawning reef corals. Mar. Biol. 143, 1185-1192 (2003).

76. Aranda, M. et al. Differential sensitivity of coral larvae to natural levels of ultraviolet radiation during the onset of larval competence. Mol. Ecol. 14, 2955-72 (2011).

77. Chua, C.-M., Schupp, P., Leggat, W. \& Baird, A. H. Effects of ocean acidification on metamorphosis: brooding and spawning larvae. Proc 12th Int Coral Reef Symp, 8D Effects of Ocean Acidification, ARC Center of Excellence, Coral reef studies and James Cook University, Cairns, Queensland, Australia 2012, July 913.

\section{Acknowledgments}

Many thanks go to the staff of the Penghu Marine Biological Research Center (PMBRC), Council of Agriculture and Biological Institute on Kuroshio (BIK), Otsuki-Kochi, Japan for logistical support, and support from members of the Coral Lab, Biodiversity Research Center, Academia Sinica (BRCAS). SK is the recipient of a postdoctoral fellowship from Academia Sinica (2012 2014). SF is part of the Taiwan International Graduate Fellowship Biodiversity Ph.D. program. This is CREEG-BRCAS contribution no. 112.

\section{Author contributions}

S.K. and C.A.C. designed the project. S.K., S.F., T.M. and L.C.G. performed the experiments. S.K., S.F. and L.C.G. analyzed the results. S.K., S.F. and C.A.C. wrote the manuscript.

\section{Additional information}

Competing financial interests: The authors declare no competing financial interests.

How to cite this article: Keshavmurthy, S., Fontana, S., Mezaki, T., González, L.d.C. \& Chen, C.A. Doors are closing on early development in corals facing climate change. Sci. Rep. 4, 5633; DOI:10.1038/srep05633 (2014).

This work is licensed under a Creative Commons Attribution-NonCommercialNoDerivs 4.0 International License. The images or other third party material in this article are included in the article's Creative Commons license, unless indicated otherwise in the credit line; if the material is not included under the Creative Commons license, users will need to obtain permission from the license holder in order to reproduce the material. To view a copy of this license, visit http:// creativecommons.org/licenses/by-nc-nd/4.0/ 